\title{
DIVERSIFICATION OF THE STRUCTURE OF EXPORT ACTIVITIES UNDER CONDITIONS OF ECONOMIC CRISIS AND LOSS OF FOREIGN MARKETS
}

\author{
๑2019 HAVRYLCHENKO 0. V.
}

UDC 339.564

JEL: E23; F15; F63; L25; L64

\section{Havrylchenko O. V. Diversification of the Structure of Export Activities Under Conditions of Economic Crisis and Loss of Foreign Markets}

The article is aimed at analyzing the theoretical and methodological approaches to diversification of Ukrainian exports under conditions of economic crisis and loss of foreign markets. The essence and reasons for export diversification are considered, the structure and tendencies of development of national exports are explored. The carried out analysis of the structure and dynamics of Ukrainian exports showed the need to diversify Ukraine's products with the purpose to gradually turn into a State with an innovative knowledge-intensive economy. This will help to restore economic growth and achieve a certain level of competitiveness. According to the results of the analysis, a large diversification of Ukrainian exports due to the gradual decrease in Ukraine's focus on the CIS markets and, in particular, on the Russian market, is specified. Ukraine for now insufficiently uses trade opportunities with countries such as the United States, Germany, Great Britain, France, Japan and Canada. In general, the State underutilizes the trade potential with 75 world countries and thus underreceives about 6 billion US dollars. It is substantiated that in the conditions of economic crisis and loss of external markets it is advisable to use the opportunities of innovative and inertial directions of diversification. A methodology for evaluating export diversification at the regional and enterprise level is proposed, which should become the basis for determining methods of diversification and identifying measures aimed at optimizing the commodity structure of exports. Understanding the main stages of export diversification of enterprise is an important condition for its further implementation.

Keywords: diversification, exports, export diversification, export structure, evaluation of export diversification, export potential.

DOI: https://doi.org/10.32983/2222-4459-2019-9-51-56

Fig.: 5. Tbl.: 1. Bibl.: 13.

Havrylchenko Olena V. - PhD (Economics), Associate Professor of the Department of Management and Business, Simon Kuznets Kharkiv National University of Economics (9a Nauky Ave., Kharkiv, 61166, Ukraine)

E-mail: hneu.gavrilchenko@gmail.com

ORCID: http://orcid.org/0000-0002-0624-2938

УДК 339.564

JEL: E23; F15; F63; L25; L64

Гаврильченко О. В. Диверсифікація структури експортної діяльності в умовах економічної кризи та втрати зовнішніх ринків збуту

Метою статmі є аналіз теоретичних і методологічних підходів до диверсифікації українського експорту в умовах економічної кризи та втрати зовнішніх ринків збуту. Розглянуто сутність та причини ди версифікації експорту, досліджено структуру та тенденції розвитку вітчизняного експорту. Проведений аналіз структури та динаміки українського експорту засвідчив необхідність диверсифікації продукиіі України, яка має на меті поступове перетворення на державу з інноваційною наукомісткою економікою. Це дозволить відновити економічне зростання та досягти певного рівня конкурентоспроможності. За результатами аналізу відмічена більша диверсифікованість українського експорту через поступове зменшення орієнтованості України на ринки країн СНД і, зокрема, на російський ринок. Україна наразі недостатньо використовує торговельні можливості з такими країнами, як Сполучені Штати Америки, Німеччина, Велика Британія, Франція, Японія та Канада. Загалом, держава недовикористовує торговельний потениіал із 75 країнами світу і недоотримує, таким чином, близько 6 млрд дол. США. Обгрунтовано, що в умовах економічної кризи та втрати зовнішніх ринків збуту доцільно використовувати можливості інноваційного та інерційного напрямів диверсифікації. Запропоновано методику оцінювання експортної диверсифікації на рівні регіону та підприємства, яка повинна стати основою при визначення методів диверсифікації та виявлення заходів, спрямованих на оптимізацію товарної структури експорту. Розуміння основних етапів здійснення експортної диверсифікації підприємства є важливою умовою їі подальшої реалізації.

Ключові слова: диверсифікація, експорт, експортна диверсифікація, структура експорту, оцінювання експортної диверсифікації, експортний потениіал.

Рис.: 5. Табл.: 1. Бібл.: 13.

Гаврильченко Олена Володимирівна - кандидат економічних наук, доцент кафедри менеджменту та бізнесу, Харківський національний економічний університет ім. С. Кузнеия (просп. Науки, 9а, Харків, 61166, Україна) E-mail: hneu.gavrilchenko@gmail.com ORCID: http://orcid.org/0000-0002-0624-2938
удК 339.564

JEL: E23; F15; F63; L25; L64

Гаврильченко Е. В. Диверсификация структуры экспортной деятельности в условиях экономического кризиса и потери внешних рынков сбыта

Целью статьи является анализ теоретических и методологических подходов к диверсификации украинского экспорта в условиях экономического кризиса и потери внешних рынков сбыта. Рассмотрены сущность и причины диверсификации экспорта, исследована структура и тенденции развития отечественного экспорта. Проведенный анализ структуры и динамики украинского экспорта показал необходимость диверсификации продукции Украины, целью которой является постепенное превращение в государство с инновационной наукоемкой экономикой. Это позволит восстановить экономический рост и достичь определенного уровня конкурентоспособности. По результатам анализа отмечена большая диверсификация украинского экспорта из-за постепенного уменьшения ориентированности Украины на рынки стран СНГ и, в част ности, на российский рынок. Украина пока недостаточно использует торговые возможности с такими странами, как США, Германия, Велико британия, Франция, Япония и Канада. В иелом государство недоиспользует торговый потенциал с 75 странами мира и недополучает, таким образом, около 6 млрд долл. США. Обосновано, что в условиях экономического кризиса и потери внешних рынков сбыта целесообразно использовать возможности инновационного и инерционного направлений диверсификации. Предложена методика оценки экспортной диверсификации на уровне региона и предприятия, которая должна стать основой при определении методов диверсификации и выявления мер, направленных на оптимизацию товарной структуры экспорта. Понимание основных этапов осуществления экспортной диверсификации предприятия является важным условием её дальнейшей реализации.

Ключевые слова: диверсификация, экспорт, экспортная диверсификация, структура экспорта, оценка экспортной диверсификации, экспортный потенциал.

Рис.: 5. Табл.: 1. Библ.: 13.

Гаврильченко Елена Владимировна - кандидат экономических наук, доцент кафедры менеджмента и бизнеса, Харьковский национальный экономический университет им. С. Кузнеца (просп. Науки, 9а, Харьков, 61166, украина)

E-mail: hneu.gavrilchenko@gmail.com

ORCID: http://orcid.org/0000-0002-0624-2938 
$\mathrm{T}$ he deterioration of political and economic relations between Ukraine and Russia and the suspension of the Free Trade Agreement with Ukraine by the Russian Federation have negatively affected the volume of exports and the size of the country's gross domestic product.

The loss of the Russian market is a serious problem for export-oriented Ukrainian producers, especially in those sectors that are largely dependent on demand from the Russian Federation, e.g., machine building [1]. A greater diversification of Ukrainian exports due to a gradual decrease in Ukraine's orientation to the markets of CIS countries and, in particular, to the Russian market, is observed.

Works of a number of scientists, namely, V. M. Dereza, O. M. Romashko, T. V. Goryanska, O. I. Shnyrkov, A. V. Kovalev, deal with investigations in this area. The aggravation of the economic crisis as well as the loss of foreign sales markets, characteristic of the current state of the national economy, require further research in this direction.

The aim of the article is to analyze theoretical and methodological approaches to diversify Ukrainian exports under conditions of economic crisis and loss of foreign markets.

The existence of different forms and levels of diversification necessitate studying this economic category (Fig. 1) [2-6].

To evaluate export diversification, it is necessary to analyze the structure and dynamics of Ukrainian exports.

According to the World Bank's Special Focus Note on foreign trade, metals and grain dominate the structure of Ukraine export, but in the last decade the focus is shifting from energy-intensive metals to agricultural products [7].

The share of energy-intensive export products cast iron and steel - has decreased due to changes in prices for imported energy carriers. Over the last two decades, economic transformations in Ukraine have been hindered by low energy tariffs inherited from past times, which brought gains to individual sectors in the short term but did not allow to carry out a much-needed industrial restructuring.

The Ukrainian iron and steel industry remains highly energy-intensive: about a quarter of the total output is produced in open-hearth furnaces that have been obsoleted by manufacturers in many countries of the world. Secondly, nature-intensive goods - primarily agricultural products, which account for more than half of the value of export products - have become an important component of Ukraine exports. Thirdly, the share of capital-intensive exports continues declining. Due to insufficient investment, the share of capital-intensive export products decreased in 2017 to a level that barely exceeds $16 \%$. And finally, the share of labor-intensive products which is the vastest resource that Ukraine has being one of the largest countries in Europe - remains very low.

In August 2018, exports amounted to USD3.7 billion. Its growth was due to an increase in all main commodity groups: food products (including grain) - by $6.5 \%$ (in July - by $8.0 \%$ ); base metals and articles of base metals by $11.2 \%$ (in July - by $19.9 \%$ ); mineral products (including ore) - by $28.0 \%$ (in July - by $25.8 \%$ ); wood and articles of wood - by $17.9 \%$ (in July - by $16.5 \%$ ); machinery and mechanical appliances - by $12.1 \%$ (in July it reduced by $7.1 \%$ ); production of or allied industries - by $7.3 \%$ (in Julyby $21.1 \%)$ (Fig. 2) [8].

A ccording to the National Bank of Ukraine, the export of goods in the 2nd quarter of 2019 amounted to USD11.2 billion. A growth occurred in the following main groups: food products - by 15.1\%; mineral products (including ores) - by $30.7 \%$; machinery and mechanical appliances - by $7.3 \%$. At the same time, a decrease was observed in exports of base metals and articles of base metals - by $14.3 \%$; products of the chemical or allied industries - by 13.6\%; wood and articles of wood - by $8.8 \%$. Geographically, the largest increase in nominal terms was observed in the exports of goods to EU countries (by USD419 million or 11.3\%), their share

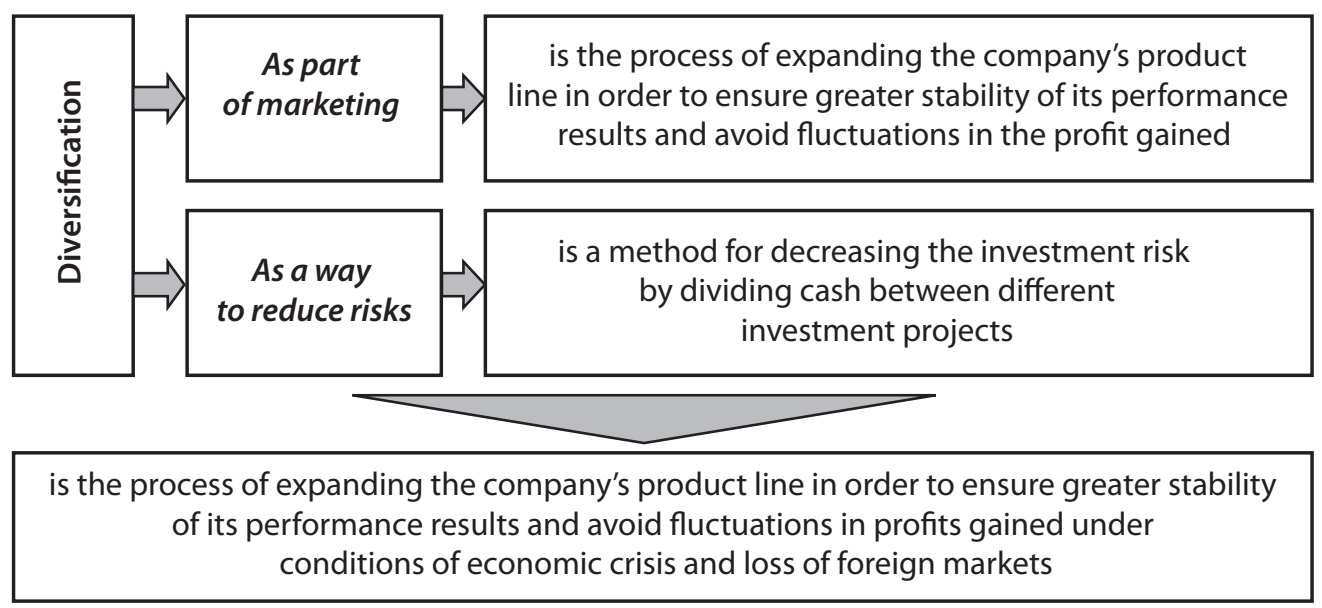

Fig. 1. Economic essence of diversification 


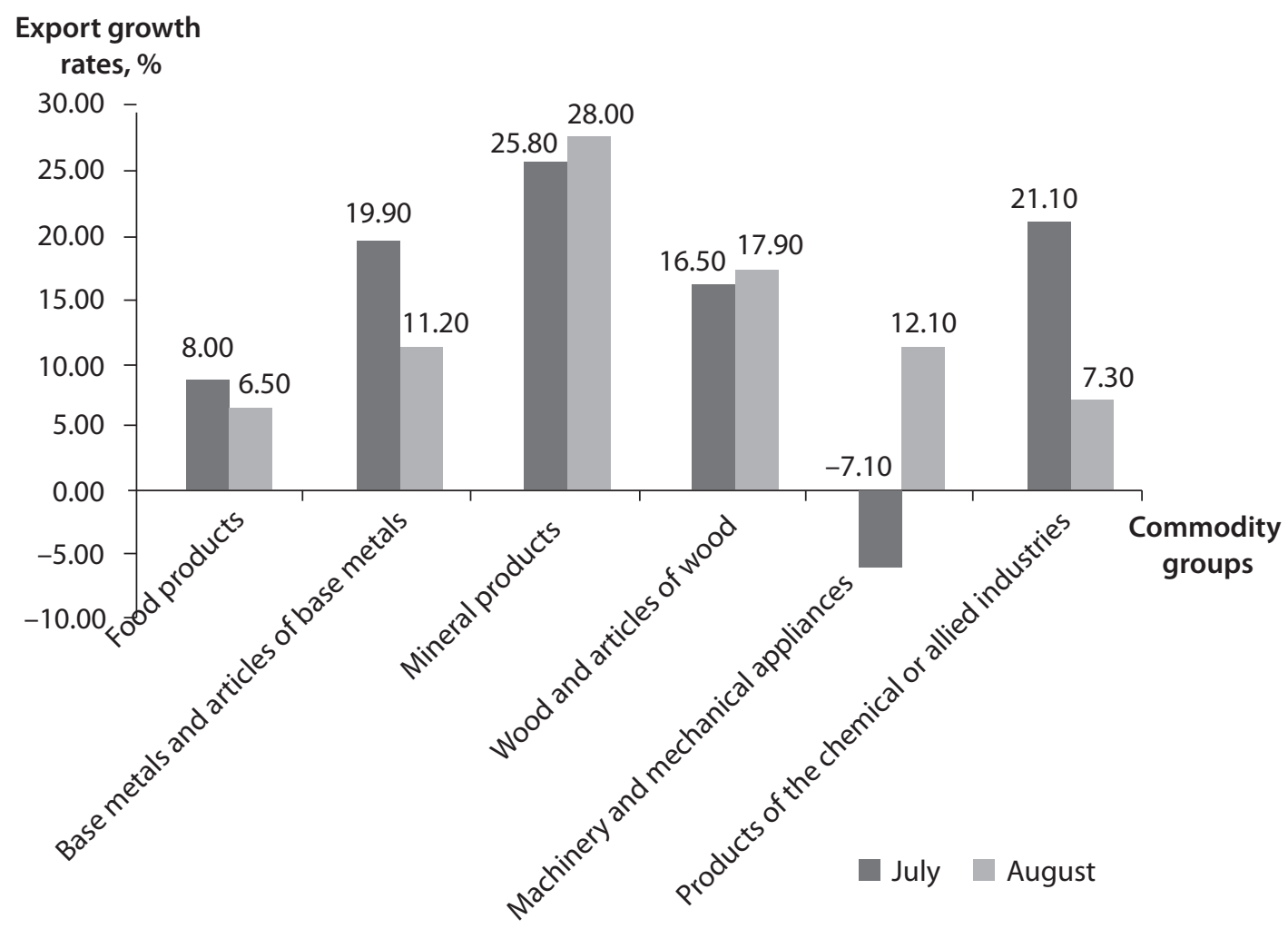

Fig. 2. Export growth rates by main commodity groups (July - August 2018)

in total exports increased to $36.8 \%$ (from $34.4 \%$ in the 2nd quarter of 2018). The exports to African countries increased by USD141 million or $13.3 \%$, their share grew to $10.8 \%$ (from $9.9 \%$ in the 2 nd quarter of 2018 ). Exports to Russia decreased by USD133 million or $16.3 \%$. The share of Russia decreased to $6.1 \%$ (from $7.6 \%$ in the 2 nd quarter of 2018) [9].

The analysis of the structure of and trends in Ukraine exports showed their low diversification. This is the most significant problem for the domestic economy since its competitiveness depends on the diversification of exports.

In general, diversification can occur in the innovative and inertial direction [10] (Fig. 3).
Under conditions of economic crisis and loss of foreign markets, it is advisable to use the opportunities of both diversification directions.

Ukraine, as an export-oriented country, is dependent on global processes. The export share in its GDP is more than 50\%, with the domestic export structure being dominated by raw materials (70\% are raw materials assets). In the case of a slowdown in world trade, the external demand for Ukrainian goods will decrease, which will result in a decrease in domestic production, deterioration in the trade balance, and depreciation of the national currency.

Ukraine has large amounts of debt. In 2019, USD2 billion will be required only to service external debts and USD4.3 billion - to pay them off.

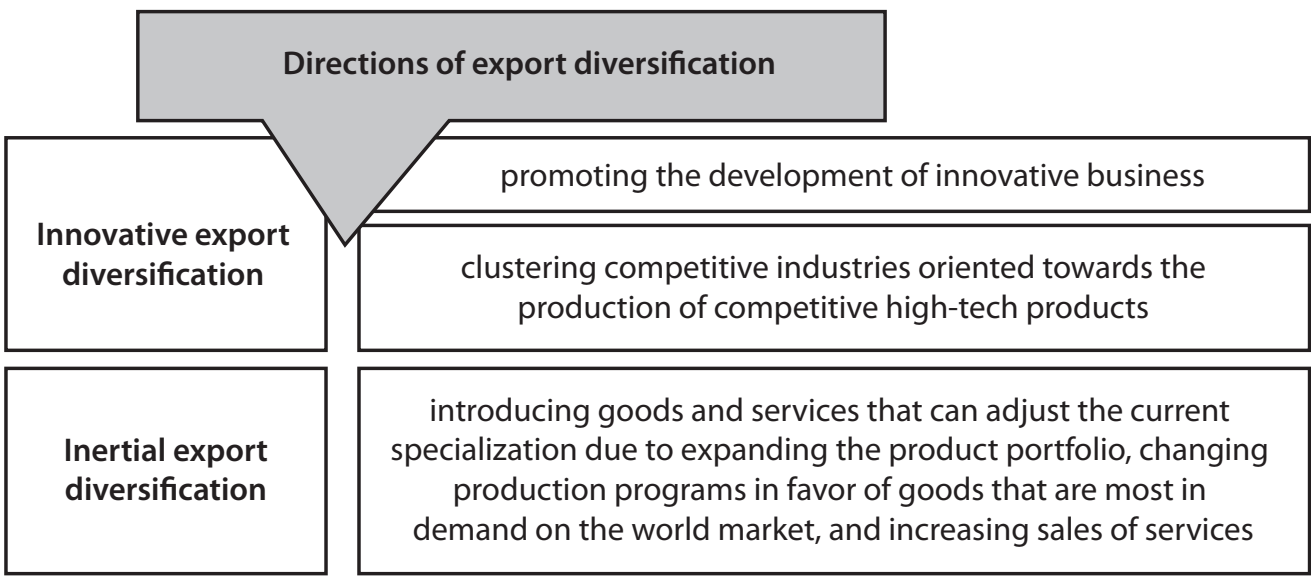

Fig. 3. Directions of export diversification 
In the event of aggravation of the global economic crisis, Ukraine will not be able to finance its external debts and attract new financing. This will lead to a decrease in the value of raw materials that prevail in its export structure, and accordingly, foreign exchange earnings will fall. And, as a consequence - devaluation, inflation, impoverishment of the population can occur.

$\circlearrowleft$ tudies show that Ukraine has not yet been sufficiently using the opportunities in its trade with 75 countries of the world, including the United States, Germany, Britain, France, Japan and Canada, which results in the loss of about USD 6 billion of its potential income ( $\mathrm{Tbl}$. 1). Although these indicators take into account the export basket as a whole, this does not mean that they reflect opportunities for expanding trade in each of the existing sectors. In the future, it is necessary to conduct a detailed analysis of markets with great export potential for each of the priority sectors [1].

Table 1

Ten major countries the opportunities of trade with which are insufficiently used by Ukraine

\begin{tabular}{|c|c|c|}
\hline Place & Country & USD \\
\hline 1 & The USA & 1935971968 \\
\hline 2 & Germany & 1150496128 \\
\hline 3 & Great Britain & 1009080704 \\
\hline 4 & France & 759456320 \\
\hline 5 & Japan & 459574272 \\
\hline 6 & China & 190861568 \\
\hline 7 & Sweden & 120487504 \\
\hline 8 & Switzerland & 76122616 \\
\hline 9 & Canada & 46610696 \\
\hline 10 & Ireland & 28484412 \\
\hline 11 & Total & 5918056535 \\
\hline
\end{tabular}

Ukrainian exports are characterized by the growing presence of Ukraine in new markets, as well as a high risk of a decrease in export volumes and a low probability of creating new products to export. This indicates the unsystematic fragmentary nature of trade relations, which may be a sign of poor product quality [1].

Some scholars emphasize the problems of methodological and organizational support for diversification management at the regional level. The development of a methodology to assess export diversification at the level of a region and enterprise should be the first step in determining mechanisms of diversification, and the results of the analysis should be the basis for determining measures aimed at optimizing the geographic and commodity structure of a region's export.

In the framework of the study, diversification is considered in the context of using a process-oriented management approach in an enterprise. This involves a sequence of stages (actions) aimed at developing various types of activities, improving existing goods, works, services and creating new ones in order to ensure operation of enterprises and enhance their competitive positions in domestic and foreign markets on the basis of the rational distribution and use of resources [11]. For further studying the diversification process, the IDEF0 standard, capable of graphically representing (with the help of graphic description language) business processes, is applied. An IDEF0 model presents a set of hierarchically interconnected diagrams, each of which is its structural unit.

To make effective management decisions regarding the export policy of an enterprise, the process of assessing the diversification of the enterprise is of importance. Its general scheme is given in Fig. 4. It can be seen that each of the functional blocks (steps) also comprises a set of corresponding actions. In particular, the "Analysis of diversification measures" block, which is among the key ones in the model, includes the following components: determining the level of diversification of production; determining the stages of obtaining added value (assessing its share in the value of marketable products); determining sales diversification (assessing the diversity of sales markets and their segments); determining the degree of similarity of types of economic activity [12].

It is also important to dwell on the main approaches to assessing enterprise diversification, which are summarized in Fig. 5 based on the results of theoretical and practical analysis $[5 ; 6 ; 13]$.

In general, the composition, content and sequence of the basic stages of assessing enterprise export diversification are determined by the following factors: availability of appropriate resources, size of the enterprise, level of staff qualifications, level of management effectiveness, foreign market research, internal motivation and goals of export activities. Understanding the main stages of enterprise export diversification is an important condition for its further implementation.

\section{CONCLUSIONS}

In the course of the research there obtained the following results:

+ the carried out analysis of the structure of and trends in Ukraine export activities revealed its low diversification, which is the most significant problem for the Ukrainian economy since its competitiveness depends on export diversification. Today, diversification of domestic products, which aims to gradually transform Ukraine into a state with an innovative knowledge-based economy, is required. This will restore economic growth and achieve a certain level of competitiveness;

+ a greater diversification of Ukrainian exports due to a gradual decrease in Ukraine's orientation to the markets of CIS countries and, in particular, to that of Russia, is noted. Ukraine has not yet sufficiently used the opportunities in its trade with 


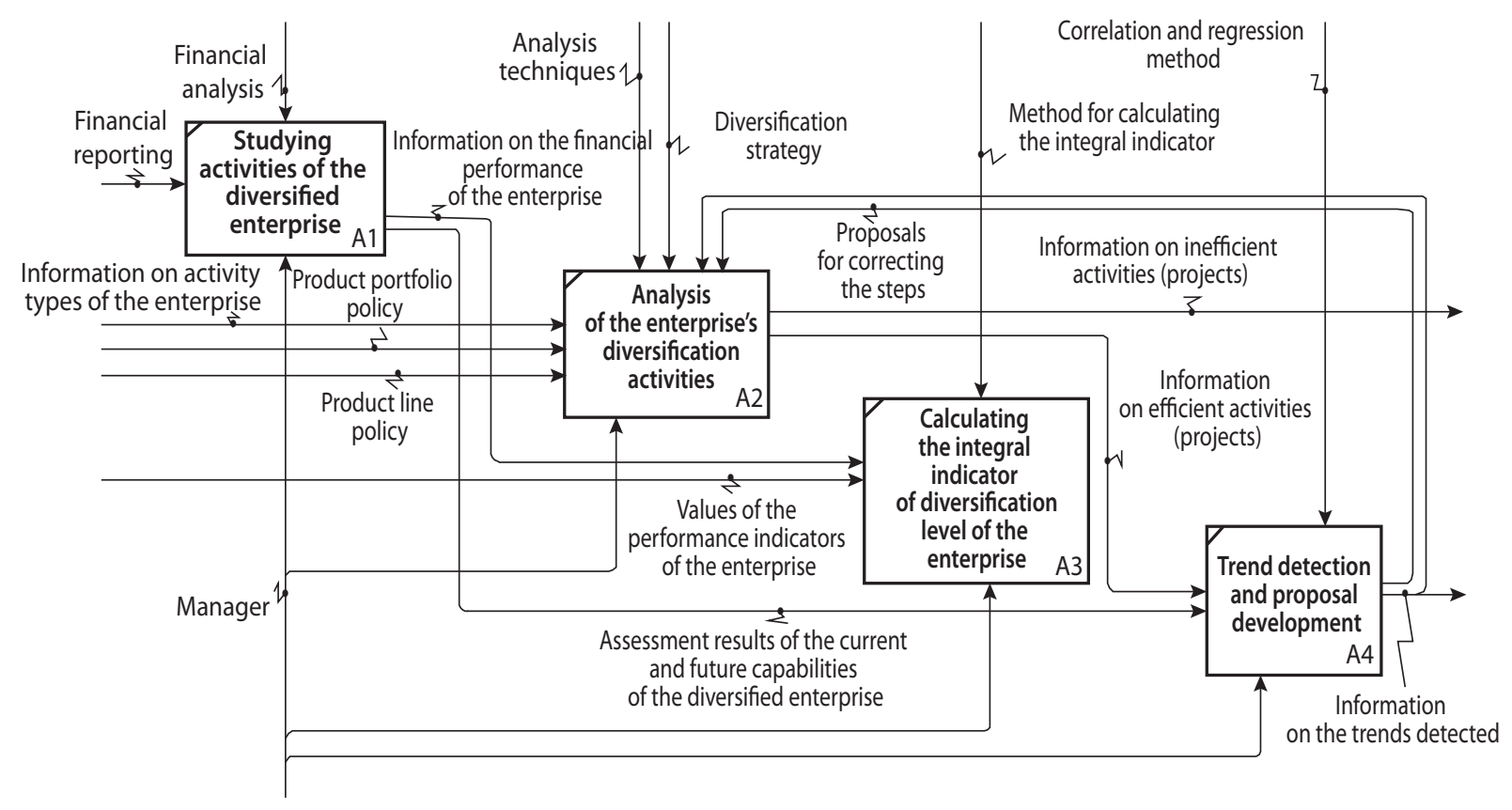

Fig. 4. Process of assessing enterprise export diversification (developed using the Ramus Educational software)

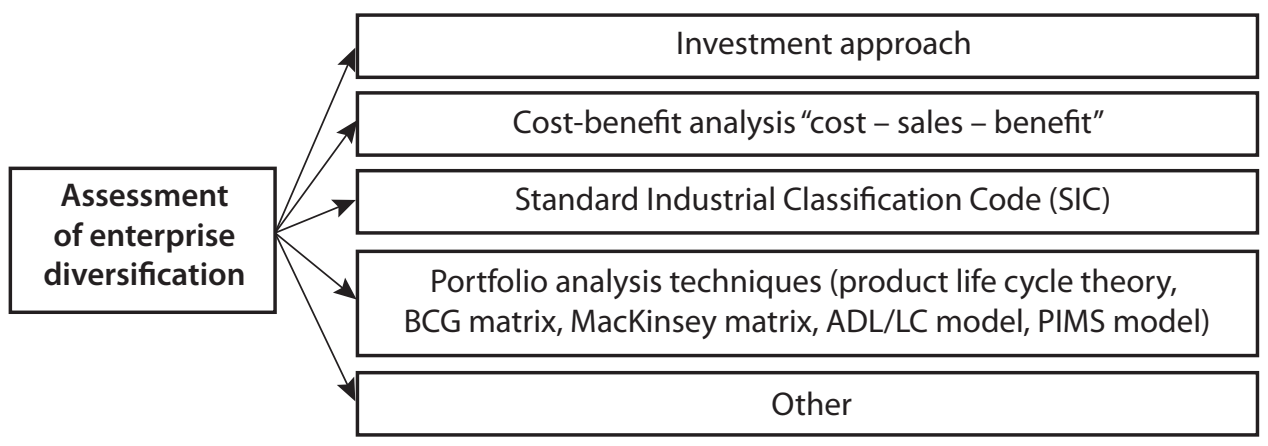

Fig. 5. Main approaches to the assessment and analysis of enterprise diversification

75 countries of the world, including the United States, Germany, Britain, France, Japan and Canada, which results in the loss of about USD6 billion of its potential income;

+ under conditions of economic crisis and loss of foreign sales markets, it is advisable to use the opportunities of innovative and inertial directions of diversification;

+ a methodology for assessing diversification of potential exports at the level of the region and enterprise, which should be the basis for determining methods of diversification and identifying measures aimed at optimizing the commodity structure of exports, is proposed.

\section{LITERATURE}

1. Дорожня карта стратегічного розвитку торгівлі України на 2017-2021 роки. URL: http://me.gov.ua/ Documents/Detail?lang=uk-UA\&id=e6ab10fa-0ad9-4fe4b8be-32f570693b64\&title=EksportnaStrategiiaUkraini-Dorozh niaKartaStrategichnogoRozvitkuTorgivli2017-2021
2. Портер М. Конкуренция / пер. с англ. М. : ИД «Вильямс», 2005. 608 с.

3. Дереза В. М. Диверсифікація виробництва і капіталу на підприємстві : монографія. Дніпропетровськ : НГУ, 2010. 124 c.

4. Ромашко О. М. Нові підходи до трактування диверсифікації діяльності підприємств. Актуальні проблеми економіки. 2014. № 11. С. 34-41.

5. Кузьмін О., Дрималовська Х. Сутність та значення диверсифікації на промислових підприємствах. Економічний аналіз. 2013. Т. 12. Ч. 3. С. 222-225.

6. Ковальов А. В. Стратегія диверсифікації промислового підприємства : монографія. Маріуполь, 2012. 212 с.

7. Ukraine. Special Focus Note: Fiscal pressures and reform options. April 10, 2018. URL: http://pubdocs.worldbank. org/en/722711523347842655/Ukraine-Special-Focus-NoteApril-2018-ENG.pdf

8. Платіжний баланс у серпні 2018 року. URL: https://bank.gov.ua/control/uk/publish/article?art_ id $=78594650$ \&cat_id $=55838$

9. Про стан платіжного балансу у II кварталі 2019 року. URL: https://bank.gov.ua/doccatalog/document?id=25173322 
10. Горянська Т. В. Конкурентні позиції експортоорієнтованих секторів економіки України. Економіка промисловості. 2012. № 1-2. С. 138-141.

11. Богуславський $\epsilon$. І., Петрук О. В. Оцінка економічної доцільності диверсифікації на підприємстві. Зовнішня торгівля:економіка, фінанси, право. 2010. № 2. С. 143-147.

12. Боломчук Б. В., Драгун Н. П. Влияние диверсификации на эффективность деятельности предприятия. Вісник Національного транспортного університету. 2009. Вип. 19. Ч. 1. С. 298-305.

13. Шнирков О. І., Резнікова Н. В. Проблема трансформації товарної експортної спеціалізації України в умовах пошуку нових ринків збуту. Актуальні проблеми міжнародних відносин. 2015. Вип. 124. Ч. 2. С. 121-129.

\section{REFERENCES}

Bohuslavskyi, Ye. I., and Petruk, O. V. "Otsinka ekonomichnoi dotsilnosti dyversyfikatsii na pidpryiemstvi" [Assessment of economic feasibility of diversification at the enterprise]. Zovnishnia torhivlia: ekonomika, finansy, pravo, no. 2 (2010): 143-147.

Bolomchuk, B. V., and Dragun, N. P. “Vliyaniye diversifikatsii na effektivnost deyatelnosti predpriyatiya" [The impact of diversification on the efficiency of an enterprise]. Visnyk Natsionalnoho transportnoho universytetu, vol. 1, no. 19 (2009): 298-305.

"Dorozhnia karta stratehichnoho rozvytku torhivli Ukrainy na 2017-2021 roky“ [Roadmap for Strategic Trade Development of Ukraine for 2017-2021]. http://me.gov.ua/Documents/Detail?lang=uk-UA\&id=e6ab10fa-0ad9-4fe4-b8be-32f5 70693b64\&title=EksportnaStrategiiaUkraini-DorozhniaKartaStrategichnogoRozvitkuTorgivli2017-2021

Dereza, V. M. Dyversyfikatsiia vyrobnytstva i kapitalu na pidpryiemstvi [Diversification of production and capital at the enterprise]. Dnipropetrovsk: NHU, 2010.
Horianska, T. V. "Konkurentni pozytsii eksportooriientovanykh sektoriv ekonomiky Ukrainy" [Competitive positions of Ukrainian export sectors]. Ekonomika promyslovosti, no. 1-2 (2012): 138-141.

Kovalyov, A. V. Stratehiia dyversyfikatsii promyslovoho pidpryiemstva [Industrial enterprise diversification strategy]. Mariupol, 2012.

Kuzmin, O., and Drymalovska, Kh. "Sutnist ta znachennia dyversyfikatsii na promyslovykh pidpryiemstvakh" [The essence and importance of diversification in industrial enterprises]. Ekonomichnyi analiz, part 3, vol. 12 (2013): 222-225.

"Platizhnyi balans u serpni 2018 roku" [Balance of payments in August 2018]. https://bank.gov.ua/control/uk/publish/article?art_id=78594650\&cat_id $=55838$

"Pro stan platizhnoho balansu u II kvartali 2019 roku" [Balance of payments in Q2 2019]. https://bank.gov.ua/doccatalog/document?id=25173322

Porter, M. Konkurentsiya [Competition]. Moscow: ID «Vilyams», 2005.

Romashko, O. M. "Novi pidkhody do traktuvannia dyversyfikatsii diialnosti pidpryiemstv" [New Approaches to the Interpretation of Business Diversification]. Aktualni problemy ekonomiky, no. 11 (2014): 34-41.

Shnyrkov, O. I., and Reznikova, N. V. "Problema transformatsii tovarnoi eksportnoi spetsializatsii Ukrainy $v$ umovakh poshuku novykh rynkiv zbutu" [The problem of transformation of commodity export specialization of Ukraine in the conditions of search for new markets]. Aktualni problemy mizhnarodnykh vidnosyn, vol. 2, no. 124 (2015): 121-129.

"Ukraine. Special Focus Note: Fiscal pressures and reform options. April 10, 2018". http://pubdocs.worldbank.org/ en/722711523347842655/Ukraine-Special-Focus-Note-April2018-ENG.pdf 